\title{
Generic versus discipline-specific writing interventions: Report on a quasi- experiment
}

\author{
Adelia Carstens $^{\mathrm{a}}$ \\ ${ }^{a}$ Department of Humanities Education, Faculty of Education, University of Pretoria, \\ Groenkloof Campus, Pretoria, 0002, South Africa \\ e-mail: adelia.carstens@up.ac.za
}

\begin{abstract}
Departing from a socio-constructivist perspective, the main purpose of the research on which this article reports was to indicate the effectiveness of both discipline-specific and generic approaches in teaching academic writing to undergraduate university students. A quasiexperimental design was followed, comparing the pre- and post-test essay ratings as well as the results of post-intervention opinion surveys. The statistical analyses of the essay scores show that both the discipline-specific and the generic interventions were effective in their own right. Although the size of the improvement on the dimensions of the scoring instrument differs, the overall improvement of the students in each group is statistically significant. Overall, the discipline-specific group performed significantly better than the generic group. Their performance was also more consistent across the dimensions of the scoring instrument. The results of the opinion survey indicate that students in both groups were generally positive about the effect of the respective interventions on their academic writing abilities. The only significant difference was the discipline-specific group's more positive experience of skills transfer. It is likely that their more positive appraisal of transferability resulted from more in-depth exposure to authentic materials, a deeper level of engagement with scholarly sources, more content knowledge, and more extensive discipline-specific writing.
\end{abstract}




\section{Introduction}

Similar to the grammar wars of the 1960s a 'war' about generic versus discipline-specific teaching of writing has been waging for at least thirty years. Scholars such as Widdowson (1983) and Hutchison and Waters (1988) have articulated a preference for wide-angled or generic interventions that emphasise learning to write in general. Other scholars in linguistics, applied linguistics and writing pedagogy, such as Faigley and Hansen (1985), Tedick (1990), Raimes, 1991, Berkenkotter and Huckin (1995), Hewings and Hewings (2001), and Biber $(1988 ; 2006)$ have expressed a clear preference for EAP programmes that emphasise disciplinary texts and practices. An intermediate position has been assumed by Dudley-Evans and St. John (1998), who articulate the belief that lecturers should first assist students to develop basic academic skills, and then facilitate the accomplishment of more specific skills.

Recently. critical and socio-constructivist approaches have steered away from a dichotomous view, focusing not on the specificity or generality but the multiplicity of academic discourses that students are required to enter and to master (Jackson 2009: 61). Bruce (2008) and Hyland (2009) have argued that university students who are registered for generally formative academic programmes, such as baccalaureate degrees, need to acquire skills that enable them to move confidently between the discourses of a number of academic disciplines. They see the literacy demands of the curriculum as involving a variety of communicative practices, including genres, fields and disciplines. Their views concur with those of Lea and Street (1989: 159), who argue that university students need "to deploy a repertoire of linguistic practices appropriate to each setting, and to handle the social meanings and identities that each evokes". The Socio-constructivist approach, which is concerned with meaning-making, rather than skills or deficits, has become known as the Academic Literacies approach; and within this approach it is no longer a central issue whether an academic writing intervention is narrowly focused (subject-specific) or has a wider disciplinary focus ("generic").

Through statistical comparison of inter-group pre-and post-test results I aim to show in this article that both narrow-angled (subject-specific) and wider-angled (generic) writing interventions could be effective if the syllabus departs from a socio-constructivist perspective. As a basic point of departure such a writing syllabus would assume that becoming academically literate entails learning the ability to handle the discursive and the lexicogrammatical complexities of genres, fields and disciplines in order to make meaning. 
First, a brief overview is given of the research design, followed by a description of the preparatory phases of the project. Subsequently, the planning, design, development administration and evaluation of each intervention is described separately, followed by a discussion of the statistical comparison of pre- and posttest results as well as the results from the opinion survey. The article is rounded out by a reflection on the relative advantages of each intervention type.

\section{Design and method}

A quasi-experimental design was used. Normally this type of design involves a pre-test and a post-test administered to all the members of a single respondent group, but in order to determine the relative effectiveness of discipline-specific and generic genre-based interventions, two groups were involved: one group receiving a programme focused on a particular academic subject (History), and the other accommodating students enrolled for a variety of humanities subjects. Table 1 represents the design schematically.

Table 1 Quasi-experimental design with two programme groups

\section{Pre-test Intervention Post-test}

Programme group A Test A1 Genre-based syllabus, with $\quad$ Test B1 history-specific materials

$\begin{array}{lll}\text { Programme group B } & \text { Test A2 } & \begin{array}{l}\text { Genre-based syllabus, with } \\ \text { materials from a range of } \\ \text { humanities disciplines }\end{array}\end{array}$

The effects of the two interventions on writing performance, as indicated by the difference between the pre- and post-test scores of the participants in each of the programmes, were statistically compared. In addition, the effect on student attitudes was elicited by means of an opinion survey questionnaire at the conclusion of each intervention, and the results were statistically described.

Next, an overview will be given of the research process, including brief background on the contextual research that preceded the evaluation, a description of the design, administration and evaluation of each intervention, a discussion of the results of the 
performance measurement and the attitude survey obtained from each intervention group, and conclusions derived about the relative effectiveness of each intervention.

\section{Background}

During 2007 a survey of writing tasks required by academic disciplines in the Faculty of Humanities was conducted at the University of Pretoria (Carstens, 2008a). Study guides from eight departments were collected, and all tasks requiring extensive writing were excerpted and analysed to determine the genres to which they belonged, as well as the text types (modes of writing) they demanded. The academic essay was found to be the genre with the highest frequency across disciplines, and thus an important genre for humanities students. The importance of this genre in undergraduate writing is underscored by Hyland's reflection on interviews with teacher trainers (2009: 132):

The essay is therefore regarded as a key acculturation practice, encouraging a critical and questioning attitude and approach to writing which involves making connections between theory and practice, drawing links between theories, evaluating research, and arguing and reasoning.

Since the materials provided by the Department of Historical and Heritage Studies contained the highest number of essay tasks, History was chosen as the discipline of focus for the discipline-specific intervention. It was decided to pitch the intervention at second-year undergraduate level, because it was argued that at this level students have already acquired a measure of metacognitive awareness about their own academic success (or lack thereof). Moreover, an intervention in the second year is still early enough to decrease the risk of extending undergraduate study related to inadequate academic literacy - a view shared with Kay and Dudley-Evans (1998). A critical genre-approach was followed for the design of the syllabi for both groups, combining Halliday's (1978) views of language with Vygotsky's (1978) ideas about learning as a collaborative and scaffolded social activity into a principled sequence of language teaching activities, within a critical framework. Both syllabi comprised a recursive application of the following phases: exploration of texts (deconstruction); joint construction of texts by the teacher and the class; independent construction of texts by learners; and critical reflection based on self-, peer and teacher evaluation (cf. Martin, 1989; 1992; Christie, 1991; Rothery, 1996; Cope \& Kalantzis, 1993; 2000).

Next, the two interventions are discussed separately. The discipline-specific intervention is discussed first, followed by an overview of the generic intervention. 


\section{Discipline-specific intervention}

Following the advice of Bhatia (1993; 2004) and Hyland (2000) on conducting research for the implementation of a disciplinary genre-based syllabus, recently published manuals on writing about History (cf. Marius \& Page, 2005; Rael, 2004; Rampolla, 2004; Storey, 2004) were studied in addition to conducting expert reviews that would bring an insider perspective to the analysis. Four senior staff members from the Department of Historical and Heritage Studies were approached to perform an expert review on an overview I had written on the relationship between disciplinary purposes and writing conventions in the field of History. From their responses it was clear that style guides and writing manuals - even those authored by historians - tend to present the conventions of the discourse community in a rather simplistic and often prescriptive way. The experts advised consultation of scholarly sources on historical writing to promote a more balanced perspective. The recommended sources included scholarly overviews of trends in historical writing from different historical periods and ideological perspectives (Burke, 2001; Evans, 1997; Marwick, 2001; Shafer, 1980; Sharpe, 2001; Tosh, 2006), as well as overviews of South African history in particular (Smith, 1988; Saunders, 1988). The expert review led to a thorough revision of my initial understanding of form function relationships in historical discourse, and suggested additional ways to investigate the characteristics of historical writing (Carstens, 2008b).

In addition to the research on the purposes of historians, and the linguistic correlates of these purposes, a literature review was conducted on syllabus design for disciplinespecific writing, with an emphasis on History (cf. Eggins, Wignell \& Martin, 1993; Rothery, 1996; Macken-Horarik, 2002; Cope \& Kalantzis, 1993; 2000; Martin, 2003, Coffin, 2003; 2006; Schleppegrell \& Achugar, 2003; Schleppegrell et al., 2004). These sources highlight three pivotal concepts that students of History have to master: time, cause and effect, and judgment, as well as the linguistic resources needed to construe these concepts in ways that are acceptable to expert members of the discourse community. In order to make the learning experience maximally useful for the respondents the syllabus focused on the same content as the History module for the second semester of the second undergraduate year, viz. GES 220 The rise and fall of segregation and apartheid. The syllabus resulting from the research is outlined below: 


\section{Study Unit 1: Introduction to historical discourse}

Why study history and why write about it?

Different perspectives to writing history (critical exploration of texts from the main traditions: Rankean (19 ${ }^{\text {th }}$ century) History, New History, Marxism, Post-modernism)

\section{Study Unit 2: Exploring preferred modes of writing in historical discourse}

Giving an overview/summarising

Telling a story/describing an event

Describing an object or an experience

Comparing and contrasting

Indicating and describing causes and effects

Arguing a case

\section{Study Unit 3: Using rhetorical modes in historical writing}

Analysing and interpreting writing prompts

Selecting appropriate modes for assignments

Writing short texts using a particular mode

\section{Study Unit 4: Getting acquainted with history essays}

The three-part structure of academic essays

(Optional) subsections

Three main essay genres in history and their prototypical structures: recording, explaining, judging and interpreting

Important stylistic, lexical and grammatical dimensions: time, causality, evaluation, and abstractness

\section{Study Unit 5: Joint composition of history essays}

Jointly analysing writing prompts to determine content, structure and language

Brainstorming and planning content

Jointly composing subsections of essays

Revising

Critiquing the essay and reflecting on the process

\section{Study Unit 6: Writing your own history essay}

Independent composition of a first and second draft, with peer and teacher feedback as well as personal reflection.

Ten students with History as a major subject in their second year of study self-selected to register for the semester course on essay writing after having been informed about the course in one of their History classes. The 14 week intervention (two contact sessions per week) 
commenced in July 2008. A part-time lecturer in the Unit for Academic Literacy, with English as a major and a master's degree in History, co-designed and taught the course. Course materials consisted of a 50 page study guide based on the syllabus, the Reader used for GES 220, the Study Manual of the Department of Historical and Heritage Studies (2006), and a number of model essays.

All students who took part in the project received the intervention along with a pretest and a post-test. The participants signed a letter of consent at the beginning of the course to allow the use of their essays and their survey responses for research purposes. The pre-test assumed the format of a 50 minute in-class essay during the second week of the module on a topic based on the content of the second-year History curriculum but was not included by the History lecturer as a homework, test or examination essay: Discuss black reaction and resistance to the Natives Land Act of 1913. Students were required to study source materials from the reader during the preceding week, and were allowed to use the reader as an in-class resource. The conditions for the post-test were exactly the same as for the pre-test, only the topic differed: Discuss how segregation affected the social and economic situation of black South Africans.

The assessment instrument was a scoring rubric comprising 15 items. The values were defined as percentage ranges (score categories) to assist the assessors in conceptualising each mark in terms of a benchmark that would resonate with generally conceived achievement levels (cf. Table 2):

Table 2 Score categories

7

$\mathbf{8 5 - 1 0 0 \%}$ Excellent
6 75-84\% Very good
5 $65-74 \%$ Good
4

$50-64 \%$

Average
3 $36-49 \%$

Below average
21 $26-35 \% \quad 0-25 \%$ Poor Very poor

An NA (not applicable) option was included for items that might not be relevant for a particular assessment.

Seven-point scales were used for 14 of the items, while the 15 th had to be rated on a two-point scale. The rationale for rating Legibility and layout on a two-point scale was to obtain a cumulative score of 100. Items 16 and 17, the Total and the Overall percentage, were only numbered for statistical purposes. Items 1-15 were clustered into four dimensions: 
Use of source material, Structure and development, Academic writing style, and

Editing. Three empirically based and internationally accredited analytic rating scales contributed input for the instrument: the TOEFL writing scoring guide; the Scoring profile of Jacobs et al. 1981 (cited by Weigle, 2002); and the Masus rating sheet of Bonanno and Jones (2007). The scoring instrument was not intended to be overtly genre-based, because the purpose of the intervention was not to teach students a particular pedagogical approach, but to assist them in learning how to write academic essays.

Before administering the instrument it was piloted on 12 in-class test essays on How Lenin and his Bolshevik government managed to remain in power from 1917 to 1924 despite numerous setbacks, which had been obtained from the Department of Historical and Heritage Studies. Adjustments were made on the basis of the relative ease and/or difficulty of use of the rating instrument, and the general agreement between the results of the analytic scoring and an impression mark. It was decided to use the NA option for item 14 Referencing technique, since referencing is normally not required for timed in-class essays, and also for item 15 Legibility and layout, since it was a single-draft, handwritten essay (as opposed to a multiple draft homework essay). Table 3 represents the scoring instrument after revision.

Table 3 Analytic scoring rubric for the assessment of academic essays

\begin{tabular}{|c|c|c|c|c|c|c|c|c|c|}
\hline & \multicolumn{9}{|l|}{ USE OF SOURCE MATERIAL } \\
\hline 1. & Relevance of source data & 7 & 6 & 5 & 4 & 3 & 2 & 1 & NA \\
\hline 2. & Integration of source data with text & 7 & 6 & 5 & 4 & 3 & 2 & 1 & NA \\
\hline 3. & Stance and engagement & 7 & 6 & 5 & 4 & 3 & 2 & 1 & NA \\
\hline \multicolumn{10}{|c|}{ STRUCTURE AND DEVELOPMENT } \\
\hline 4. & Thesis statement: clarity and focus & 7 & 6 & 5 & 4 & 3 & 2 & 1 & NA \\
\hline 5. & Evidence in support of thesis & 7 & 6 & 5 & 4 & 3 & 2 & 1 & NA \\
\hline 6. & Conclusion & 7 & 6 & 5 & 4 & 3 & 2 & 1 & NA \\
\hline 7. & Paragraph development & 7 & 6 & 5 & 4 & 3 & 2 & 1 & NA \\
\hline \multicolumn{10}{|c|}{ ACADEMIC WRITING STYLE } \\
\hline 8. & $\begin{array}{l}\text { Syntax: phrase and clause structure, } \\
\text { sentence length }\end{array}$ & 7 & 6 & 5 & 4 & 3 & 2 & 1 & NA \\
\hline 9. & Concord and tense & 7 & 6 & 5 & 4 & 3 & 2 & 1 & NA \\
\hline 10. & Linking devices & 7 & 6 & 5 & 4 & 3 & 2 & 1 & NA \\
\hline 11. & Technical lexis & 7 & 6 & 5 & 4 & 3 & 2 & 1 & NA \\
\hline 12. & Style (formality; rhetorical mode) & 7 & 6 & 5 & 4 & 3 & 2 & 1 & NA \\
\hline \multicolumn{10}{|c|}{ EDITING } \\
\hline 13. & Spelling and punctuation & 7 & 6 & 5 & 4 & 3 & 2 & 1 & NA \\
\hline 14. & Referencing technique & 7 & 6 & 5 & 4 & 3 & 2 & 1 & NA \\
\hline & Legibility and layout & \multicolumn{4}{|c|}{$\operatorname{good} 2$} & \multicolumn{3}{|c|}{ poor 0} & NA \\
\hline 16. & Total & & & & & & & & \\
\hline 17. & Overall percentage & & & & & & & & \\
\hline
\end{tabular}


The pre-test as well as the post-test essays were scored independently by myself (Rater 1) and the class lecturer (Rater 2), using the revised rubric. Fairly large discrepancies occurred between the scores of the two raters, regarding both the pre-test and the post-test. On average the pre-tests were scored $7.1 \%$ lower by Rater 2 than by Rater 1 . The converse was true for the post-tests, which were on average scored 6.6\% higher by Rater 2 than by Rater 1 . Possible explanations for the discrepancies are that (1) the two raters focused on different aspects of essay quality: content in the case of Rater 2, and form in the case of Rater 1; (2) Rater 2 had ample experience in rating History papers, whereas Rater 1 had 25 years of experience in the assessment of academic writing; and (3) Rater 2's scores might have subconsciously been influenced by a desire to prove the effectiveness of the intervention.

On the basis of the large discrepancy between the scores of the two raters and the results of the preliminary statistical analyses, it was jointly decided by the researcher and the statisticians who supervised the quantitative process to use only Rater 1's scores.

\section{Generic intervention}

The 14 week generic intervention, designed and presented by myself, commenced in February 2009. Similar to the discipline-specific intervention it was framed upon the Teaching Learning Cycle of the Australian genre school, which draws upon a considered combination of Hallidayan Systemic Functional Grammar, Vygotskyan Social Constructivism and the Critical Literacies approach in academic development. Because disciplines in the humanities have varying purposes, essay structure could not so easily be linked to conceptual content. Thus, argumentation served as an important structuring principle in the module. The syllabus comprised the following themes and subthemes: 
Study Unit 1: Academic discourse(s)

What is academic discourse?

Is there only one academic discourse?

\section{Study Unit 2: Exploring preferred modes of writing in the humanities}

Giving an overview/summarising

Telling a story/describing an event

Describing an object or an experience

Comparing and contrasting

Indicating and describing causes and effects

Arguing a case

Study Unit 3: Academic arguments: formulating claims

Fact and opinion

What is a claim/thesis?

Positioning of the main thesis of an essay

Types of claims (factual; causal; evaluative; recommendations)

\section{Study Unit 4: Academic arguments: supporting claims}

Types of support (comparison; definition; well-chosen examples; statistics; appeals to audience needs; appeals to authority; addressing a counterargument)

Using appropriate types of support for different types of claims

Study Unit 5: The structure of academic essays

The three-part structure of academic essays (introduction, body, conclusion)

Developing an essay: waves of information (essay level; paragraph level; sentence and clause level)

\section{Study Unit 6: Engaging with other voices}

Conveying standard views

Allowing others to speak

Making your own voice audible

\section{Study Unit 7: Composing an academic essay independently}

Planning (analysing the essay prompt; generating ideas; doing research; outlining)

Two cycles of writing and review (writing the first draft; peer review and feedback; correction; lecturer review and feedback; correction; submission of final version)

Critical reflection on process and product 
Eleven students enrolled for the module: Two were registered for a general bachelor's programme, five for programmes in political science, three for a degree specialising in languages, and one BCom student. The subjects for which they were registered included Accounting, Criminology, Economics, English, Journalism, History, History of Art, Political Sciences, Philosophy, Psychology, Sociology, and Visual Studies. Their sociodemographic profile could be summarised as follows: 2 white males with Afrikaans as their mother tongue; 1 white male with English as his mother tongue; 2 white females with Afrikaans as their mother tongue; 1 black female with Portuguese as her mother tongue, 4 black females with an African language as their mother tongue, and 1 black male with an African language as his mother tongue.

Course materials consisted of a 100 page study guide/workbook that was based on the presyllabus, and contained a selection of texts from a variety of disciplines in the humanities; and a reader (hard copy) comprising four broad-focused articles on the theme selected for the content of the module, viz. Poverty in Africa. This theme was suggested by lecturers from the departments who contributed materials for the writing task survey, because of its relevance across disciplines. In addition, a partially interactive Blackboard-based website was designed, which contained administrative information about the lecturer, the content and assessment as well as a calendar with important dates. Via a link to the library students had access to a variety of scholarly articles (for which copyright clearance was obtained) and web resources. Additional class notes and the list of topics for the final examination were uploaded to folders on the home page.

Similar to the discipline-specific intervention, all students who enrolled for the module had to write a pre-test and a post-test. The pre-test assumed the format of a 50 minute in-class essay during the second week of the module on the topic Poverty in Africa. All participants received the reader (containing articles on general aspects of poverty in Africa) a week in advance, and were requested to prepare for the pre-test essay. They were allowed to use the reader as an in-class resource. The pre-test did not count towards the students' final marks, as they had not received any tuition on essay writing at that point. Before writing the pre-test consent was obtained to use unattributed extracts from participants' essays as well as the analytic scores awarded by the raters.

Similar to the discipline-specific intervention the post-test assumed the format of a 50-minute in class-essay at the conclusion of the 14-week module. However, in order to accommodate their respective subjects of focus, the students could choose from a list of topics on various issues relating to poverty in Africa, which had been requested from the 
relevant academic departments. Table 4 shows the topics that were chosen by the students in the essay exam:

Table 4 Essay topics chosen by students in the generic group

Topic (and description)

Subject-field

No. of

students

To what extent was poverty an inevitable by-product of History

1

European colonialism in Africa?

Whose obligation is it to do something about poverty in Philosophy

society: the rich or the poor?

Whose obligation is it to do something about the moral Philosophy problem of poverty: the poor or the government?

Analyze the poem "London" by William Blake (in the

English literature

Norton Anthology of Poetry) OR "An abandoned

bundle" by Oswald Mtshali (in the Paperbook of South

African Poetry ed. Chapman) paying close attention to

the way the poem depicts both physical and spiritual

poverty.

Discuss how Boesman and Lena are dehumanised by

English literature

3 poverty and racial discrimination in Athol Fugard's

Boesman and Lena. Refer closely to the text throughout your discussion.

The policy gap and poverty

Political Science

1

Evaluate the United Nations' Millennium Development

Economics

Goals (MDGs) as a global strategy to arrest poverty, by referring to the MDGs' normative as well as practical

contribution to the plight of the poor.

Famine and hunger are often associated with poverty.

Sociology

How can this be combated through policy initiatives?

The pre- and the post-test essays were scored independently by me (Rater 1), and a part time lecturer with more than 20 years experience in teaching English literature, language and 
academic literacy, as well as a doctorate in Applied Linguistics (Rater 2). The assessment instrument was the same as for the discipline-specific intervention (Table 3).

Rater 1 scored students higher than Rater 2 on both the pre-tests and the post-tests: on average the pre-tests were scored 3.4\% higher by Rater 1 than by Rater 2, and the post-tests were scored $2.4 \%$ higher by Rater 1 than by Rater 2 . The correlation coefficient of the scores of the two raters is 0.96 for the pre-test and 0.97 for the post-test, therefore warranting the use of the average of the two raters' scores as a measure of each student's performance.

\section{Results and discussion}

Performance on the pre- and post-tests

For each intervention descriptive statistics were used to indicate the improvement per candidate, per item, and per cluster (dimension) of items. Thereafter statistical tests were conducted to calculate the probability that the improvement was statistically significant.

Table 5 juxtaposes the means of the two intervention groups, first on the pre-test and then on the post-test on each of the four primary dimensions of the analytic scoring instrument as well as overall. The last two columns show the improvement of each of the groups between the pre- and the post-tests per dimension.

Table 5 Comparison of the two groups in terms of their improvement

Dimension Mean: pre-test Mean: post-test Improvement

\begin{tabular}{lcccccc}
\hline & $\begin{array}{c}\text { Subject- } \\
\text { specific }\end{array}$ & $\begin{array}{c}\text { Cross- } \\
\text { disciplin- } \\
\text { ary }\end{array}$ & $\begin{array}{c}\text { Subject- } \\
\text { specific }\end{array}$ & $\begin{array}{c}\text { Cross- } \\
\text { disciplin- } \\
\text { ary }\end{array}$ & $\begin{array}{c}\text { Subject- } \\
\text { specific }\end{array}$ & $\begin{array}{c}\text { Cross- } \\
\text { disciplin- } \\
\text { nary }\end{array}$ \\
\hline $\begin{array}{l}\text { 1. Use of source } \\
\text { materials }\end{array}$ & $51 \%$ & $54 \%$ & $69 \%$ & $64 \%$ & $18 \%$ & $10 \%$ \\
\hline $\begin{array}{l}\text { 2. Structure and } \\
\text { development }\end{array}$ & $56 \%$ & $49 \%$ & $74 \%$ & $64 \%$ & $18 \%$ & $15 \%$ \\
\hline $\begin{array}{l}\text { 3. Academic } \\
\text { writing style }\end{array}$ & $62 \%$ & $67 \%$ & $81 \%$ & $74 \%$ & $19 \%$ & $7 \%$ \\
\hline $\begin{array}{l}\text { 4. Editing } \\
\text { And }\end{array}$ & $64 \%$ & $64 \%$ & $81 \%$ & $63 \%$ & $17 \%$ & $-1 \%$ \\
\hline
\end{tabular}

\section{Overall}


According to Table 5 there is a $10 \%$ "overall" difference between the groups in terms of their improvement as a result of the particular intervention. The table further shows that the improvement of the discipline-specific group was about equal on the three primary dimensions measured by the analytic pre- and post-test assessment (between 17\% and 19\%), while the overall improvement of the generic group was more moderate (8\%), and also more variable: $10 \%$ on Use of source materials, $15 \%$ on Structure and development, $7 \%$ on Academic writing style and $-1 \%$ on Editing.

The Wilcoxon signed-rank test (SPSS version 17; Williams, Sweeney \& Anderson, 2009) was used to assess if the differences between the pre- and post-test ratings were significant for each of the two interventions. The Wilcoxon signed-rank test is a nonparametric test that is suitable for the analysis of small samples, as in the present case. The test indicates the probability of a significant difference between pre- and post-test ratings, and is appropriate for comparing data obtained from the same participants - in this case the pre- and post-tests written by each respondent who participated in each of the interventions. Table 6 juxtaposes the results from the two interventions.

Table 6 Significance of the difference between the improvement of the two groups

One-sided p-values

\begin{tabular}{lll}
\hline Dimension & Discipline-specific
\end{tabular}
1. Use of source materials
0.004
0.022

2. Structure and development

0.006

0.003

3. Academic writing style

0.003

0.004

\section{Editing}

0.008

0.321

\section{Overall}

0.002

0.001

Both interventions proved to be successful in their own right. The p-values for three of the four dimensions - Use of source materials, Structure and development and Academic 
writing style - were well below 0.05 for each group, and thus the improvement was statistically significant for each. Only on Dimension 4, Editing, did the improvement of the generic group not prove to be significant $(\mathrm{p}=0.321)$, which was predictable in light of the fact that the performance of the group as a whole decreased by $1 \%$ between the pre-test and the post-test.

In order to establish whether the difference between the two interventions (disciplinespecific and generic) was statistically significant, the Mann-Whitney U-test was applied. The Mann-Whitney U-test is the non-parametric equivalent of the independent samples T-test for assessing whether two independent samples of observations come from the same distribution, which is particularly useful for small samples. In statistical terms it assesses the ranked positions of scores in two different groups. If there are significant differences between the two groups, the p-value associated with the test statistic will be smaller than 0.05. The main finding was that overall, the discipline-specific group performed significantly better than the generic group. A p-value of 0.043 was obtained (cf. Table 7 below).

Because of the significance of the overall difference found between the disciplinespecific and the generic interventions, separate Mann-Whitney U-tests were run for each of the four main dimensions of the holistic scoring instrument. Table 7 shows the p-values for the four dimensions, as well as the overall value. Two-sided values are reported because one group was not necessarily expected to perform consistently better than the other.

Table 7 Two-sided p-values of the scores from the Mann-Whitney U-test Dimension Two-sided p-values per dimension 
According to the separate Mann-Whitney U-tests, the discipline-specific group did not perform significantly better than the generic group on every dimension. A significant difference was only found with respect to Dimension 3, Academic writing style, and Dimension 4, Editing (p-value, in each case $=0.02$ ). For both these dimensions significant differences were expected on the basis of the simple comparison in Table 5 above. Since the value of the fourth dimension, Editing, was derived from a single item (item 13) a generalisation can not be made. It can only be concluded that the discipline-specific group succeeded better than the generic group in improving their spelling and appropriate use of capital letters.

No significant difference was found with regard to Dimension 2, Structure and Development ( $p$-value $=0.809$ ). This was not surprising, because according to the tabulated comparison, the improvement of the two groups differs by a mere 3\%: $18 \%$ for the discipline-specific group and $15 \%$ for the generic group. According to my own belief, the basic principles of developing an argument at various levels of the text (the whole essay, paragraph and sentence) are largely subject-neutral, and can be taught and learned successfully through a combination of explicit instruction, model texts and sufficient exercise.

Similarly, no significant difference between the two groups in terms of Dimension 1, Use of source materials ( $\mathrm{p}$-value $=0.223$ ), was indicated by the Mann-Whitney U-test. This finding might seem to be contrary to the result of the simple comparison in Table 5. A larger sample may result in a significant $p$-value.

In order to establish whether individual items may have influenced the p-values on the main dimensions of the scoring instrument, Mann-Whitney U-tests were run for all 13 individual items of the holistic scoring instrument (cf. Table 8).

The more detailed analysis in Table 8 identifies specific items that may have exaggerated or diluted the p-values of the dimensions. In the case of dimension 3 Syntax (item 8, with a pvalue to 0.005 , and thus significant at the $5 \%$ level) and Linking devices (item 10, with a pvalue of 0.099 , indicating significance at the $10 \%$ level) greatly influenced the p-value for the dimension as a whole. On the other hand, although the difference between the intervention groups regarding dimension 1, Use of source materials, was not significant according to the Mann-Whitney test $(p=0.223)$ the $p$-value for one of the three items comprising the dimension (Item 1, Relevance of source materials) indicates a statistical difference between the generic and the discipline-specific groups at the $10 \%$ level $(\mathrm{p}=$ $0.051)$. 
Table 8 Two-sided p-values of the raters' scores from the Mann-Whitney U-test per item

\begin{tabular}{|c|c|}
\hline Dimension & Item \\
\hline
\end{tabular}

$\begin{array}{llll}\text { 1: Handling of sources } & \text { 1 Relevance } & 0.051 & \\ & \text { 2 Integration } & 0.349 & 0.223 \\ & \text { 3 Stance and engagement } & 0.654 & \end{array}$

2: Structure and development
4 Thesis statement
0.756
5 Development of argument
0.863
6 Conclusion
0.557
7 Paragraph development
0.223

0.809

3: Academic writing style
8 Syntax
0.005
9 Concord and tense
0.314
10 Linking devices
0.099
11 Lexis
0.114
12 Style
0.387

0.020

\begin{tabular}{|c|c|c|}
\hline 4: Editing & $\begin{array}{l}13 \text { Spelling and } \\
\text { capitalization }\end{array}$ & 0.020 \\
\hline
\end{tabular}

Overall

16

0.043

It should be noted that the findings regarding the individual items were not surprising, and plausible explanations for significant differences (or a lack thereof) were not hard to find. Items 1 and 8 will be explored in more detail. With regard to Item 1 it can be argued that the History students actively engaged, quantitatively and qualitatively (in both their History classes and the academic literacy classes), with scholarly sources on a specific theme, viz. the Native Land Act of 1913. Furthermore, they became familiar with the core sources included in their History reader, which was also used for the essay writing module. In contrast, the mixed group was exposed to fairly generic sources on the topic of focus, Poverty in Africa. They might have been less motivated than the discipline-specific group to engage regularly with scholarly sources on this topic, since it was not necessary to internalise the content for being assessed in their core modules. Furthermore, the students in this group were allowed to write their final exam essay on any of the topics provided by lecturers in the Faculty; and some of them chose topics that seemed to be interesting, but fell outside the 
focus of the academic programmes for which they were registered. For instance, one of the students who was registered for a degree in Journalism, chose the topic Whose obligation is it to do something about poverty in society: the rich or the poor? This topic requires familiarity with philosophical ways of arguing. The student managed to structure her essay well and to invoke evidence from relevant sources, but failed to exhibit mastery of the discourse of Philosophy. Against this backdrop it is not surprising that the discipline-specific group's improvement was significantly more than the generic group on Item 1. The p-value of Item 8 can be explained as follows: Although none of the interventions paid specific attention to the improvement of syntactic well-formedness, the discipline-specific group had the advantage of becoming familiar with the historian's ways of formulation through extensive reading and writing in the discipline. During the course of the semester they wrote at least eight full academic essays on topics related to the history of Apartheid in South Africa. The respondents in the mixed group - with the exception of the two students majoring in Philosophy - wrote only three full essays on aspects of poverty during the course of the semester-long essay writing intervention.

Although plausible explanations can be found for the p-values of the primary dimensions, with specific reference to the impact of individual items, the findings raise questions about the validity of the construct underlying the scoring grid. A replication of this study, using a larger sample and conducting a factor analysis may shed light on issues of validity.

Next we turn to the opinion survey to investigate the role that students' attitudes may have played in their improvement between the pre- and the post-test. The rationale for conducting the survey was the hypothesis that the success of academic literacy interventions depend on learners' interest and engagement, which translate into motivation and skills transfer (cf. Nunan, 1991; Grabe \& Stoller, 2002).

\section{Opinion survey}

\section{Conceptual framework}

At the conclusion of each of the two interventions all the participants filled in a questionnaire comprising 29 statements. These statements operationalised the typical features of critical genre-focused syllabi, viz. Scaffolding, Social Apprenticeship, Needs-driven Syllabus and Critical Orientation. The success of the syllabus in focusing on the content and conventions of the target domain(s) (Target-focused syllabus) was not included as it was assumed that second-year students would not be adequately equipped to judge the fulfilment of 
disciplinary requirements. Instead, the feature Skills transfer was operationalised in order to prove/refute the most important criticism against genre-focused approaches: that these approaches would revert back to the 'scientific approach' to language teaching, foster transmission pedagogy and cultivate passive learners (cf. Prior, 1995). Table 9 explicates the construct that was operationalised in the questionnaire:

Table 9 Explication of the five dimensions of the construct underlying the opinion survey

Dimension

1. Staged and scaffolded teaching and learning model

\section{Description}

Explicit pedagogical framework (visible pedagogy)

Modelling (using exemplars as model texts)

Gradual progress from maximal teacher- and peer-assistance to complete independence

Explicit teaching of discourse structure

Explicit teaching of lexicogrammar
2. Purposeful social apprenticeship
Aimed at attaining goals that are important to expert members of the discourse community into which the student wishes to be assimilated

Learning through actively engaging with authentic subject matter, while being supervised by the master/lecturer, and assisted by peers
3. Needs-driven syllabus

4. Critical orientation
Content and pedagogy are attuned to the wants, needs and skills level of the learner.

\section{Skills transfer}

Explicit knowledge of the conventions of valued academic genres empowers students and heightens metacognitive awareness to facilitate self-evaluation

Critical analysis of texts enables students to unveil ideology and hidden agendas

Students are encouraged to challenge prescriptive genre conventions
The principles of structure and language that are taught can be transferred to other contexts and genres (therefore it cannot be asserted that this approach stifles creativity or cultivates passive learners). 
Students had to indicate their responses to the statements comprising the questionnaire (see Appendix) on standard five-point Likert scales. The response options were 'strongly agree', 'agree', 'uncertain', 'disagree' and 'strongly disagree'. Thirteen of the 29 statements were phrased in a negative way, meaning that 'strongly agree' and 'agree' indicated a negative evaluation of the particular characteristic of the course, whereas 'strongly disagree' and 'disagree' indicated a positive evaluation. The scales for 13 of the statements (statements 1, 4, $5,7,13,16,19,2021,23,24,25$ and 27) had to be reversed to enable the correct interpretation of the responses. Descriptive statistics were used to analyse the data.

In order to compare the results of the post-intervention opinion surveys, a MannWhitney U-test was performed for each of the five theoretical dimensions of the opinion survey, viz. (1) Staged and scaffolded teaching and learning model, (2) Purposeful social apprenticeship, (3) Needs-driven syllabus, (4) Critical orientation and (5) Skills transfer. For each of the two interventions the total score for the items comprising each dimension was obtained. The scales were reversed where necessary to facilitate uniform polarity. The spiderweb plot represented as Figure 1 shows the differences between the means of the responses of the two groups (after reversal of the scales with a negative polarity):

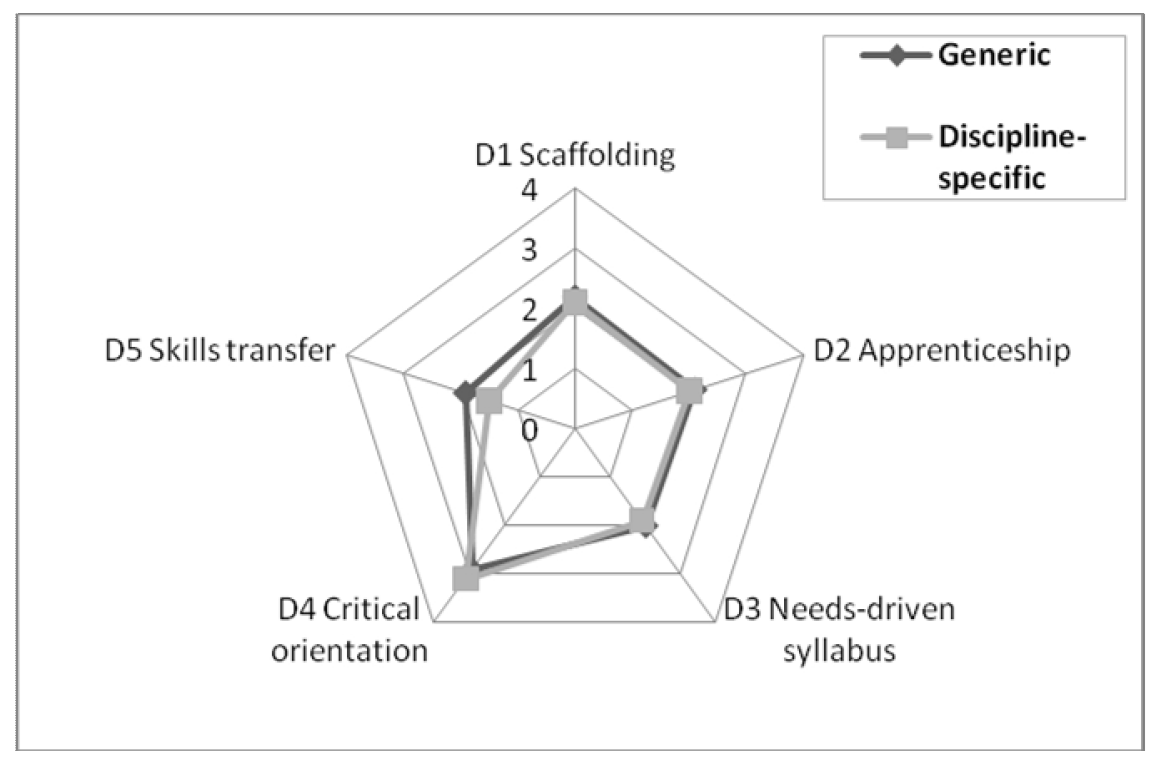

Figure 1 Means of the two groups on the five dimensions of the opinion survey

From the graph it can be read that, on average, both groups felt reasonably positive about the way that a staged and scaffolded teaching and learning intervention assisted them in improving their academic writing skills (dimension 1); that both groups were, to a large extent, convinced of the positive effects of learning as a member of a discourse community 
(dimension 2); and also that the module had addressed their personal needs and goals reasonably well (dimension 3 ). On the other hand, both groups were uncertain as to the effect that the course might have had on their development of a critical orientation (dimension 4). Although both groups were positive about the transferability of the skills they had learned (dimension 5), a predictably higher rating on this dimension (between positive and extremely positive) was obtained from the discipline-specific group.

According to the Mann Whitney U-test (Table 10) the overall opinion of the two groups about the intervention did not differ significantly. As suggested by the differences in the statistical means for Skills transfer, a significant difference (at the $10 \%$ level) was found on this dimension:

Table 10 Two-sided p-values of the opinion survey findings from the Mann-Whitney U-test

\section{Dimension}

1 Staged and scaffolded teaching and learning model

2 Purposeful social apprenticeship

3 Needs-driven syllabus

4 Critical orientation

5 Skills transfer

Overall
P-value

0.209
0.568

0.130

The discipline-specific group was thus more inclined to think that the skills they had learned in the course were indeed transferable to other contexts. Further analysis of the data showed that although some students in the generic group were convinced that they could apply what they had learned to more than one discipline, others were much less positive about the transferability of the skills.

\section{Conclusion}

From the multifaceted comparison described in this article it can be concluded that socioconstructivist approaches with a strong genre focus are effective to teach writing in Higher 
Education. Both the discipline-specific and the generic interventions administered to secondyear undergraduate humanities students at the University of Pretoria proved to be effective in their own right. In both cases there was a significant improvement in students' writing abilities between the pre-test and the post-test: For the discipline-specific intervention a pvalue of 0.002 was obtained, while a p-value of 0.001 was obtained for the generic group.

A statistical comparison of the performance of the two groups shows that the students who took part in the discipline-specific intervention improved more than those who took part in the generic intervention. Percentage-wise the discipline-specific group improved by $18 \%$ overall, while the generic group improved by $8 \%$ - a difference which proves to be significant according to the Mann-Whitney U-test: $p=0.004$. The improvement of the discipline-specific group was also more consistent across the four dimensions of the scoring instrument than the improvement of the generic group.

Although both groups expressed fairly positive opinions about the intervention in general, the discipline-specific group was significantly more positive than the generic group about the transferability of the skills they had learned. A p-value of 0.086 was obtained on the Mann-Whitney U-test, which means that the difference is significant at the $10 \%$ level.

These results corroborate the findings by previous researchers in terms of the effectiveness of genre-based writing interventions for university students, irrespective of whether the programme is narrowly or more broadly focused. Interventions that are more sharply focused on a particular discipline seem to be more effective because motivation is enhanced through deeper engagement with authentic subject matter, and through both intensive and extensive writing in a particular conceptual and thematic framework. 
STAGED, SCAFFOLDED TEACHING \& LEARNING MODEL

1. Throughout the module I have been uncertain about what I $\begin{array}{lllllll}1 & 2 & 3 & 4 & 5\end{array}$ would learn.

2. The model essay that was provided by the lecturer helped $\begin{array}{lllllll}1 & 2 & 3 & 4 & 5\end{array}$ me to understand what I should aim for.

3. The module taught me how to structure an academic essay $\begin{array}{llllllll}1 & 2 & 3 & 4 & 5\end{array}$ and its different parts.

4. It is best to start writing an essay without a clear plan, and $\begin{array}{llllll}1 & 2 & 3 & 4 & 5\end{array}$ to develop the structure of your essay as you go along.

5. The class notes on reporting verbs (such as say, assert, claim, contend, suggest, reckon, etc.) were helpful in improving my academic writing style.

6. In my opinion a student's creativity is dampened by explicit guidelines on essay structure.

7. As the semester went on I depended more and more on the $\begin{array}{lllllll}1 & 2 & 3 & 4 & 5\end{array}$ lecturer for writing assistance.

8. Doing various shorter exercises before writing a full essay $\begin{array}{lllllll}1 & 2 & 3 & 4 & 5\end{array}$ helped me to master important skills.

9. The module taught me how to construct an academic $\quad \begin{array}{lllllll}1 & 2 & 3 & 4 & 5\end{array}$ argument in my discipline of focus.

10. If a student knows how to analyse an essay prompt he/she $\begin{array}{lllllllll}1 & 2 & 3 & 4 & 5\end{array}$ has a good chance of succeeding in the task.

\section{PURPOSEFUL SOCIAL APPRENTICESHIP}

11. If you want to write a good academic essay you have to be $\begin{array}{lllllll}1 & 2 & 3 & 4 & 5\end{array}$ clear about what you want to achieve with it.

12. It is easier to learn by tackling writing tasks together with a $\begin{array}{lllllll}1 & 2 & 3 & 4 & 5\end{array}$ lecturer and other students than doing it all by yourself.

13. If you share your thoughts about essay-writing with your $\quad \begin{array}{lllllll}1 & 2 & 3 & 4 & 5\end{array}$ classmates they might steal your ideas.

14. Interacting with people who share my academic interests gave me an idea of how it would be to work in an organisation where employees share common goals. 


\section{NEEDS-DRIVEN SYLLABUS}

15. The module fulfilled my expectations.

16. The study materials (study guide and reader) did not challenge me enough.

17. The lecturer was interested in addressing my personal $\quad \begin{array}{lllllll}1 & 2 & 3 & 4 & 5\end{array}$ needs.

18. The most important questions I had about essay-writing $\quad \begin{array}{lllllllll}1 & 2 & 3 & 4 & 5\end{array}$ have been answered.

19. The module is too difficult for second-year students.

20. The module is too easy for second-year students.

$\begin{array}{lllll}1 & 2 & 3 & 4 & 5\end{array}$

$\begin{array}{lllll}1 & 2 & 3 & 4 & 5\end{array}$

\section{CRITICAL ORIENTATION}

21. It is empowering to know how to write in the genres valued by academics.

22. If one of my academic lecturers says that it is forbidden to refer to myself ("I") in academic writing, I will take issue with him/her.

23. One should accept the content of textbooks and academic $\quad \begin{array}{llllll}1 & 2 & 3 & 4 & 5\end{array}$ articles as true.

24. It is impossible to criticise one's own work.

$\begin{array}{lllll}1 & 2 & 3 & 4 & 5\end{array}$

25. Empowerment in tertiary education means that students should be allowed to write as they speak.

\section{SKILLS TRANSFER}

26. The course has contributed towards improving my writing $\begin{array}{llllllll}1 & 2 & 3 & 4 & 5\end{array}$ ability in English.

27. I find it difficult to apply the principles we have learned in $\begin{array}{llllllll}1 & 2 & 3 & 4 & 5\end{array}$ this course to writing tasks in other subjects.

28. Much of what I have learned about essays I can also use $\quad \begin{array}{lllllll}1 & 2 & 3 & 4 & 5\end{array}$ when writing reports and other text types.

29. Since I started this module my marks for written work in $\begin{array}{lllllll}1 & 2 & 3 & 4 & 5\end{array}$ other subjects have improved. 


\section{REFERENCES}

Berkenkotter C \& Huckin TN. 1995. Genre knowledge in disciplinary communication: cognition/culture/power. Hillsdale, NJ: Lawrence Erlbaum.

Bhatia VK. 1993. From description to explanation in language teaching. In Bhatia, VK (ed.) Analysing genre. language use in professional settings. London/New York: Longman, pp 147-206.

Bhatia VK. 2004. Worlds of written discourse. A genre-based view. London: Continuum.

Biber D. 1988. Variation across speech and language. Oxford: Oxford University Press.

Biber D. 2006. University language. A corpus-based study of spoken and written registers. Amsterdam: Benjamins.

Bonanno H \& Jones J. 2007. Measuring the academic skills of university students. Sydney $3^{\text {rd }}$ edition. Sydney: University of Sydney.

Bruce I. 2008. Academic writing and genre. London: Continuum.

Bureau for Institutional Research and Planning. Total number of students as in November 2009. Analysis according to home language. Retrieved February 2010, from https://www.up.zc.za/services/birap/Beraad/interest.php

Burke P. (ed.) 2001. New perspectives on historical writing. Pennsylvania: Pennsylvania State University Press.

Carstens A. 2008a. Preferred genres and rhetorical modes in the humanities and social sciences. Language Matters 39(1): 49-65.

Carstens. A. 2008b. A multidirectional model for tertiary-level disciplinary writing. $S A$ Journal for Language Teaching 42(1): 81-97.

Christie F. 1991. Literacy in Australia. Annual Review of Applied Linguistics 12: 142-155.

Coffin C. 2003. Reconstruing the past: settlement or invasion? In Martin JR \& Wodak R (eds) Re/reading the past: Critical and functional perspectives on time and value. Amsterdam: Benjamins, pp 219-246.

Coffin C. 2006. Historical discourse. The language of time, cause and evaluation. London: Continuum.

Cope B \& Kalantzis M. (eds) 1993. Powers of literacy: a genre approach to teaching writing. London: Falmer Press. 
Cope B \& Kalantzis M. 2000. Introduction: Multiliteracies: the beginnings of ideas. In Cope B \& Kalantzis M (eds) Multiliteracies. Literacy learning and the design of social futures. London and New York: Routledge, pp 3-8.

Department of Historical and Heritage Studies. 2006. Study Manual. Pretoria: University of Pretoria.

Eggins S, Wignell P \& Martin JR. 1993. The discourse of history. Distancing the recoverable past. In Ghadessy, M (ed.) Register analysis: theory and practice. London: Pinter, pp 75-109.

Evans RJ. 1997. In defence of history. Great Britain: Granta Books.

Faigley L \& Hansen, K. 1985. Learning to write in the social sciences. College Composition and Communication 36(2): 140-149.

Grabe W \& Stoller F. 2002. Teaching and researching reading. London: Pearson.

Halliday MAK. 1978. Language as a social semiotic. The social interpretation of language and meaning. London: Edward Arnold.

Hewings A \& Hewings M. 2001. Approaches to the study of disciplinary variation in academic writing. In Hall DR \& Hewings, A (eds) Innovation in English language teaching. Routledge: London and New York, pp 71-83.

Hyland K. 2000. Disciplinary discourses: social interactions in academic writing. Harlow: Longman.

Hyland K. 2009. Academic Discourse. London: Continuum.

Jackson F. 2009. EAP course design within a context of institutional change and crossdisciplinary collaboration: factors shaping the creating of 'writing for commerce'. Per Linguam 25(2): 61-81,

Kay H \& Dudley-Evans T. 1998. Genre: What teachers think. ELT Journal 52(4): 308-314.

Lea, MR \& Street B. 1998. Student writing in Higher Education: an academic literacies approach. Studies in Higher Education 23(2):157-172.

Macken-Horarik M. 2002. "Something to shoot for": a systemic functional approach to teaching genre in secondary school science. In Johns AM (ed.) Genre in the classroom. Multiple perspectives. London: Lawrence Erlbaum, pp 43-72.

Marius R \& Page ME. 2005. A short guide to writing about history $5^{\text {th }}$ edition. New York: Pearson Education. 
Martin JR. 2003. Making history in re/reading the past. In Martin, JR \& Wodak, R (eds) Re/reading the past: critical and functional perspectives on time and value. Amsterdam: John Benjamins, pp 19-57.

Marwick A. 2001. The new nature of history. Knowledge, evidence, language. Basingstoke, Hampshire: Palgrave.

Nunan D. 1991. Language teaching methodology: A textbook for teachers. London:

Prior P. 1995. Redefining the task: an ethnographic examination of writing and response in graduate seminars. In Belcher D \& Braine G (eds) Academic writing in a second language. Norwood NJ: Ablex Publishing, pp 47-82.

Rael P. 2004. Reading, writing and researching history. A guide for college students.

[Online] Available http://academic.bowdoin.edu/WritingGuides/prael@,bowdoin.edu. Accessed 2007/07/31.

Raimes A. 1991. Instructional balance: from theories to practices in the teaching of writing. In Alatis, J (ed.) Georgetown University roundtable on language and linguistics. Washington DC: Georgetown University Press.

Rampolla ML. 2004. A pocket guide to writing in history $4^{\text {th }}$ edition. Boston MA: Bedford/St. Martin's.

Rose D. 2009. Writing as linguistic mastery: The development of genre-based literacy pedagogy. In The Sage handbook of writing development. London: Sage, pp 152-166.

Rothery J. 1996. Making changes: developing an educational linguistics. In Hasan R. and Willimans G (eds) Literacy in society. London: Longman, pp 86-123.

Saunders C. 1988. the making of the South African past. Major historians on race and class. Cape Town: David Philip.

Schleppegrell M \& Achugar M. 2003. Learning language and learning history: A Functional Linguistics approach. TESOL Journal 12(2): 21-27

Schleppegrell MJ, Achugar M \& Oteiza T. 2004. The grammar of history: Enhancing content-based instruction through a functional focus on language. TESOL Quarterly 38(1): 67-93.

Shafer RJ. 1980. A guide to historical method. Belmont, California: Wadsforth Publishing. 
Sharpe J. 2001. History from below. In Burke, P (ed.) New perspectives on historical writing $2^{\text {nd }}$ edition. University Park, Pennsylvania: Pennsylvania State University Press, pp 25-42.

Smith K. 1988. The changing past. Trends in South African historical writing. Johannesburg: Southern Book Publishers.

Storey WK. 2004. Writing History. A guide for students $2^{\text {nd }}$ edition. Oxford: Oxford University Press.

Tedick DJ. 1990. ESL writing assessment: Subject-matter knowledge and its impact on performance. English for Specific Purposes 9: 123-143.

Tosh J. 2006. The pursuit of history. London/New York: Pearson/Longman.

Vygotsky LS. 1978. Mind in society: the development of higher psychological processes. Cambridge: Cambridge University Press.

Weigle SC. 2001. Assessing writing. Cambridge: Cambridge University Press.

Williams TA, Sweeney DJD \& Anderson R. 2009. Contemporary Business Statistics. Oklahoma City: South-Western. 